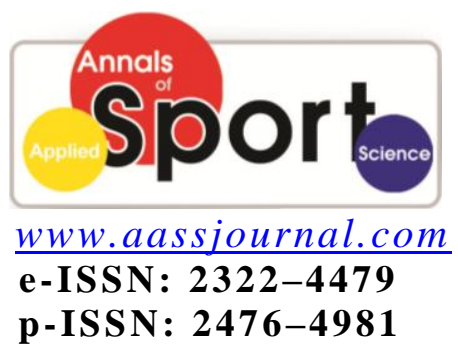

Driginad Article

Received: 27/08/2015

Accepted: 15/11/2015

\title{
Identify and Analysis of Performance Evaluation Indicators of Iranian Goalball Coaches
}

\section{${ }^{1}$ Hossein Abdolmaleki, ${ }^{2}$ Zahrasadat Mirzazadeh", ${ }^{*}$ Mahboobeh Allahyari, ${ }^{3}$ Mahboobeh Ramezani Farokhad}

1. Faculty of Sport Sciences, Karaj Branch, Islamic Azad University, Karaj, Iran.

2. Department of Sport management, Faculty of Sport Sciences, Ferdowsi University of Mashhad, Mashhad, Iran.

3. Department of Industrial Engineering, Islamic Azad University, Najaf Abad Branch, Najaf Abad, Iran.

\begin{abstract}
Assessment of performance in the sports industry is an important issue which has attracted the attention of many researchers. One of the important human resources that have a prominent role in the success of sports organizations are coaches and especially club coaches that smallest decisions of them can affect the performance of the entire organization. The purpose of this study was to explore the most important criteria for evaluating the performance of Goalball coaches in Iran. The population consists of all coaches and head coaches and players working in Iran professional Goalball leagues. According small size of the population, sample was considered statistically equal that finally 37 coach and 110 Goalball players (total of 147) questionnaires were collected for data analysis. In this study, a researcher made questionnaire was used. The factors in performance evaluating of Goalball in perspective of coaches were behavioral factor, technical-education factor, team and individual management, experience factor and finally preservation and promotion of team, respectively. Results showed that there are significant differences between coaches and players in combination of education, experience and the management team and individual. But there was no significant difference between the views of coaches and players in the rest. The most important factor in performance evaluating of coaches was technical-education factors, researcher offer to club managers, only by the number of wins and losses of their coaches, not to choose or dismiss their coaches and use from sub-component obtained for choose or dismiss their coaches.
\end{abstract}

Key Words: Performance Evaluation, Coach, Goalball, Blind and Visually Impaired.

Corresponding Author:

Zahrasadat Mirzazadeh

E-mail: z.mirzazadeh@um.ac.ir 


\section{INTRODUCTION}

After the Second World War, in 1946 Austrian man named Hanz Lorenzen and a Germany named Sepp Reindle invented Goalball for wounded rehabilitation. Each Goalball team consists of 3 main players, who are positioned opposite to each other at the end of Goalball court. This sport field is planned and developed for blind people or individuals who have eye impairments; of course, ordinary people can play this sport as an entertainment. The International Blind Sport Association (IBSA) is responsible for passing and altering rules as well as holding international competencies. Goalball is one of Paralympic sport. When the handicapped federation in Iran established, initially blind sport was under the supervision of this federation. Goalball was the first sport field, which was planned and executed formally in order to involve blind people in sport and its activity commenced at the provinces in Iran. In 1990, the first Goalball championship competition was held in Tehran in which 6 teams participated, after that year Goalball had a noticeable growth in Iran and each year the number of participant teams as well as the level of competitions in Iranian championship competencies increased significantly. In the recent years, Iranian Goalball has developed in international level. We can point out that the most noticeable honor of Iranian in Goalball was getting the third universal champion in 2007 and getting Asian champion In 2010 (1).

In the recent system, improving individual and organizational performance has been one of the main goals of each active and alive organization. optimal performance has been considered as an independent area of organizational studies by experts and managers due to the fact that optimal performance is associated with organizational effectiveness and efficiency; in addition, organizations should allocate the main part of their efforts to the study of processes and their effective performances in terms of improving their performance and become successful in order to survive and progress in the competitive world (2). MacLean and Zakrajsek (1996) believe that performance evaluation entails organizationally oriented behaviors; therefore, performance evaluation is essential trend for all occupations regardless their level and complexity. Performance evaluation is involved in evaluating human factor in organizationally oriented impacts and defined as the trend of evaluating formal performance; besides, Performance evaluation includes feedbacks so that performance adjustment can be done on the base of these feedbacks (3). Sport science researchers believe that coaches are the most effective members in sport federations, whose performance is the outcome of organization performance and their performance is a mirror, which reflects the whole federation achievements. As a result, the defeats or victories of sport organizations in achieving goals and implementing strategies are reflected and assessed in national teams' defeats or victories (1). Moreover, sport pundits believe that the selection of national teams' coaches as well as performance evaluation and measurement are the main duties of sport federation; plus, this factor has influence on continuing coaches' cooperation in national levels (4). Coaching career is a sensitive and stressful career so that organizing practices, communication with athletes, participation in sport competition, communication with managers and different media, specialized information maintenance and acquiring various mental and management skills are competencies which have turned coaches' duties into difficult task (5). From one side a coach, who is responsible for leading the team under these circumstances, should have unique characteristics. From the other side, the coach should be informed about other ideas about his/her behavior, decisions and 
communication patterns as well as others evaluation of his/her performance. As a result, the coach is able to compare others feedbacks with his/her personal evaluation of outcomes and provide an appropriate personal optimization plan for improving performance (6). According to researchers' and coaches' idea, coaches' activities are not only limited to sport competition day, but also include all 3 phases (before the competition, during the competition, after the competition) each of which includes various responsibilities; therefore, a coach, who has the responsibility of leading the team in this level, should have a range of characteristics in order to score other club members' efforts with the minimum errors (5).

As a result, with a cursory glance at the identity of Iranian Goalball coaching occupation and significant progress in this field in recent years we conclude that if appropriate criteria and indexes are used in measuring their performance, we can expect a remarkable improvement in national teams' performance. Among the various types of sport fields for blind people and visually impaired, Goalball is popular and Paralympics sport field, which has special status among these people in Iran. Without a doubt, Iranian Goalball has experienced an improvement recently; besides, the structure of Goalball club leagues has established and strengthened; therefore, the shortage of scientific research about coach's performance evaluation is obvious. In order to maintain and improve these developments, it is essential to do scientific researches and studies about coaches' performance evaluation.

Myers et al. (2006) evaluated the university sport coach's competencies from athletes' point of view. That evaluation was done in 4 dimensions, each of which had subsets (7). Coaches' Association of British Columbia (2007) offered a complete series of different questionnaires for evaluating coach's performance in different levels (8).
These questionnaires are divided into 5 categories: non-professional coaches, professional coaches, higher level coaches, self-evaluation questionnaires and evaluation by athletes. The questions of questionnaires are designed in terms of 6 characteristics namely: organizational and formation skills, educational skills, personal communication skills, group communication skills, safety and management skills and coaches' personality skills. In these questionnaires each question related to each characteristic has its weight and its scores are proportional to its weight; consequently, the sum of these scores is the coaches' total score (8). Kavussanu et al. (2008) investigated the effectiveness of coaches from the athletes 'point of view and the coaches' idea. Their findings showed that coaches had higher average scores in comparison with their athletes in all dimensions of effectiveness namely: motivation effectiveness, strategy effectiveness, technique effectiveness and character building effectiveness. Also mentioned is that researches in other fields have shown that people have the tendency to evaluate themselves more than others, such that they justify their results (6). Barron et al. (2009) evaluated sport league coaches' knowledge in Michigan in terms of first aids and sport injuries. He concluded that coaches do not have adequate knowledge in this area. It is worth noting that in this research coaches scored themselves 65 out of 100.Efforts were made to collect the results of 343 coaches' self-evaluation (9). Competencies related to annual plan (3.58), determination of practice and competition locations (4.07) and coaching and personal-educational competencies (3.69) were three competencies investigated in this research (9).

In one of the newest researches, Peng and Ming (2011) in their research aimed to select indexes to evaluate high-level Wushu teams in terms of literature, questionnaire, AHP and statistics in order to establish a management system for performance 
evaluation. Their findings indicate that the performance evaluation system of Wushu teams in the first level includes 4 indexes (practice management, team performance management, competition management and team player management). Additionally, 17 criteria were in the second level (10). Moreover, Myers (2013) determined five factors namely: game strategy, physical conditions, technical conditions, motivational conditions and character building conditions (11).

Taking into consideration the mentioned literature, the question arises thus: what are appropriate criteria and indexes for Goalball coaches' evaluation performance system? In other words, what are appropriate criteria and indexes for measuring coaches' performance? After developing indexes for performance evaluation, the question of how important and influential each index of the performance evaluation system and the rank of each index is then answered. The purpose of this research is to investigate the most important criteria and indexes for Iranian Goalball coaches performance evaluation from coaches' and players', who took part in various leagues (super league, first league team and second league team). In addition, ranking these criteria provide the opportunity to determine differences between their attitudes and players' attitudes in order to provide essential feedbacks for them and recognize their developmental needs.

\section{MATERIALS AND METHODS}

The current research is an applicable research from goal aspect and used the descriptive-survey approach of data collection, which is investigated in the form of field work.

Participants. The statistical population for this study was taken from all head coaches, coaches and players who work in various Iranian leagues (super leagues, first league and second league teams) in 2014. With taking into consideration the low number of population, the statistical sample considered and selected equal to the population statistics. As a result, 37 coaches and 110 players and totally 147 participants cooperated with the researcher.

Tools. The data collection tool was a researcher-made questionnaire, which was planned in tow sections. The first section includes demographic variables such as age, the level of education, coaching or playing record and the level of coaching.

The second section includes Iranian Goalball coaches' performance evaluation criteria, which were planned through studying research literature, the investigation of journals and scientific documents, using Iranian Goalball coaches' performance evaluation forms and following investigations which had similar questionnaires.

The initial questionnaire was made of 100 items, which decreased to 60 indexes in the following phase through semi-leaded surveys with 8 Iranian Goalball coaches and experienced experts. Finally 60 indexes which had the highest frequency and the most emphasis in surveys and journals were selected as indexes for Goalball coaches' performance evaluation. The validity of questionnaire is content validity. In order to ensure the validity of questionnaire, the initial questionnaire was distributed among several sport management pundits; in the following step, the final questionnaire was designed according to their ideas. Subsequently, to confirm reliability of questionnaires and initial investigation of population statistics regarding to its limitations, 30 questionnaires were selected from distributed questionnaires randomly and 0.83 Coronbach's alpha coefficient was computed through SPSS software.

Statistical Analysis. In the level of inferential statistics, the data distribution was investigated through Shapiro- Wilk test to ensure the collected data are normal. In the next phase, regarding the normality of data distribution, exploratory factor analysis and confirmatory factor analysis and 
independent $\mathrm{t}$ test were used. Significance level was acceptable at $\mathrm{p} \leq 0.05$.

\section{RESULTS}

In this paper exploratory factor analysis were used to determine influential coaches' performance evaluation factors. The researcher estimated the adequacy of volume sample through KMO test in this way, there searcher managed to find if the number of variables are sufficient to predict each factor. In addition, Bartlett test was used to determine if items have enough correlation with each other (Table 1).

Table1. Results of Bartlett and KMO test

\begin{tabular}{ll}
\hline variable & results \\
\hline KMO analyses to estimate the size of sample & 0.800 \\
$\mathrm{X}^{2}$ & 6321.98 \\
Bartlett test to ensure factors division & 0.001 \\
\hline
\end{tabular}

According to Leach, Bert and Morgan report (2005), the scale of KMO should be more than 0.7 and the scale of Bartlett should be less than 0.05 . The results of table 1 indicate that the volume of sample was appropriate for exploratory factor analysis and variables had appropriate correlation with each other.

In the next stage, 5 factors were obtained through executing varimax rotation order. Afterwards the internal correlation of each variable in factors was recognized and computed through Cronbach's alpha. Factors which had internal correlation more than 0.639 were selected as appropriate factors for the explanation of coaches' performance evaluation in the sample. As a result, 5 obtained factors allocated 62.72 percent of variance to themselves. These factors are elaborated below in terms of their rank respectively. The behavioral factor, technical-educational factor, experience factor, maintenance and development of team factor and individual - team management factor.

Investigating the results of variables indicates that 57 questions out of 60 questions about Goalball coaches' performance evaluation in the questionnaire had equal or higher standardized loading than that of basic criteria; besides 3 questions had less standardized loading than that of the basic criteria which were omitted from factor analysis.

The results of confirmatory factor analysis are examined in the following stage, which shows the goodness of fit indexes for the data in terms of appropriate statistical indexes. Table 2 illustrates the appropriate goodness of fit indexes according to $\mathrm{X} 2$ and other indexes. You can see this table in appendix.

In the pictorial diagram the output of Amos Graphics software shows the results of the confirmatory factor analysis of questionnaire, according to this diagram each of 5 factors have significant effect; therefore, they justify the previous results.

Based on Shapiro-Wilk test, distribution of all data were normal; so, independent sample t test was used to compare coaches approach and players approach about ranking performance evaluation criteria (Table 3). The results of independent t test shows that there is significant difference among technical-educational factor, individual- team management factor and experience factor, while there is no significant difference between behavioral Factor and maintenance and development factor. 
Table 2. The results of exploratory factor analysis questionnaire

\begin{tabular}{|c|c|c|c|c|}
\hline Factor & Variables & $\begin{array}{l}\text { Standardized } \\
\text { loading }\end{array}$ & $\begin{array}{l}\text { Coronbach's } \\
\text { alpha }\end{array}$ & $\begin{array}{l}\text { Percentage of } \\
\text { factor variance }\end{array}$ \\
\hline \multirow{13}{*}{$\begin{array}{l}\text { Behavioral } \\
\text { factor }\end{array}$} & $\begin{array}{l}\text { Relaxation and controlling players } \\
\text { stress during the competition }\end{array}$ & 0.702 & \multirow{13}{*}{0.80} & \multirow{13}{*}{17.14} \\
\hline & Ability to absorb players trust & 0.695 & & \\
\hline & $\begin{array}{l}\text { The emphasize and consideration of } \\
\text { players' positive characteristics }\end{array}$ & 0.659 & & \\
\hline & $\begin{array}{l}\text { The control and supervision on } \\
\text { executing players plans according to } \\
\text { their duties definitions }\end{array}$ & 0.648 & & \\
\hline & $\begin{array}{l}\text { The ability to increase team players } \\
\text { tactics }\end{array}$ & 0.644 & & \\
\hline & $\begin{array}{l}\text { The maintenance of motivation and } \\
\text { valuing the reserved players }\end{array}$ & 0.646 & & \\
\hline & $\begin{array}{l}\text { The reconstruction of players' physical } \\
\text { and mental power after the } \\
\text { competition }\end{array}$ & 0.669 & & \\
\hline & $\begin{array}{l}\text { Performance improvement } \\
\text { promotion of team and players }\end{array}$ & 0.671 & & \\
\hline & Honesty in credits and deeds & 0.653 & & \\
\hline & $\begin{array}{l}\text { Polite and respectful behavior with } \\
\text { team players }\end{array}$ & 0.640 & & \\
\hline & Provoking motivation in players & 0.681 & & \\
\hline & $\begin{array}{l}\text { Positive thinking spirit and } \\
\text { transferring it to players }\end{array}$ & 0.677 & & \\
\hline & $\begin{array}{l}\text { Dealing with the margins of team and } \\
\text { avoiding the team from margins }\end{array}$ & 0.689 & & \\
\hline \multirow{15}{*}{$\begin{array}{l}\text { Technical - } \\
\text { educational } \\
\text { factor }\end{array}$} & $\begin{array}{l}\text { The ability to analyze the game and } \\
\text { competition }\end{array}$ & 0.700 & \multirow{15}{*}{0.81} & \multirow{15}{*}{13.29} \\
\hline & $\begin{array}{l}\text { High ability to conduct team during } \\
\text { competition }\end{array}$ & 0.699 & & \\
\hline & Ability to train and practice players & 0.688 & & \\
\hline & $\begin{array}{l}\text { Establishing regulation and the } \\
\text { discipline of team }\end{array}$ & 0.646 & & \\
\hline & $\begin{array}{l}\text { Using strategies and techniques } \\
\text { proportional to each competition }\end{array}$ & 0.737 & & \\
\hline & $\begin{array}{l}\text { Believe in applying knowledge and } \\
\text { science in Goalball }\end{array}$ & 0.658 & & \\
\hline & Maintaining team integration & 0.654 & & \\
\hline & $\begin{array}{l}\text { Goal setting for each player and all } \\
\text { the team members }\end{array}$ & 0.641 & & \\
\hline & 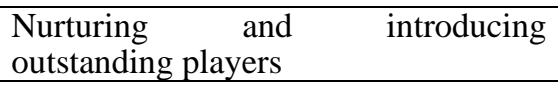 & 0.677 & & \\
\hline & $\begin{array}{l}\text { Being decisive in decision making } \\
\text { and having static convicts }\end{array}$ & 0.653 & & \\
\hline & Interest in coaching occupation & 0.701 & & \\
\hline & $\begin{array}{l}\text { Precise scheduling for the execution } \\
\text { of team plans, players plans and } \\
\text { coaches plans }\end{array}$ & 0.645 & & \\
\hline & $\begin{array}{l}\begin{array}{l}\text { Planning and executing the } \\
\text { appropriate practice }\end{array} \\
\end{array}$ & 0.671 & & \\
\hline & $\begin{array}{l}\text { The determination of players duties } \\
\text { definition }\end{array}$ & 0.661 & & \\
\hline & $\begin{array}{l}\text { Controlling on team bench during the } \\
\text { competition }\end{array}$ & 0.657 & & \\
\hline
\end{tabular}


Table 2. continued

\begin{tabular}{|c|c|c|c|c|}
\hline Factor & Variables & $\begin{array}{c}\text { Standardized } \\
\text { loading }\end{array}$ & $\begin{array}{l}\text { Coronbachs's } \\
\text { alpha }\end{array}$ & $\begin{array}{l}\text { Percentage of } \\
\text { factor variance }\end{array}$ \\
\hline \multirow{8}{*}{ Experience factor } & Achieve honor as a coach & 0.643 & \multirow{8}{*}{0.73} & \multirow{8}{*}{11.64} \\
\hline & The level of coaches' education & 0.705 & & \\
\hline & $\begin{array}{l}\begin{array}{l}\text { Passing coaches' } \\
\text { developing that }\end{array} \\
\end{array}$ & 0.843 & & \\
\hline & $\begin{array}{l}\text { Coaching experience in national and } \\
\text { club teams }\end{array}$ & 0.681 & & \\
\hline & Popularity and fame & 0.717 & & \\
\hline & $\begin{array}{l}\text { Membership in national and } \\
\text { International professional associations }\end{array}$ & 0.664 & & \\
\hline & $\begin{array}{l}\text { Coaching in younger age groups or } \\
\text { coaching in low level leagues }\end{array}$ & 0.644 & & \\
\hline & $\begin{array}{l}\text { Having first level coaching } \\
\text { qualification }\end{array}$ & 0.640 & & \\
\hline \multirow{10}{*}{$\begin{array}{l}\text { Maintenance and } \\
\text { development of } \\
\text { team factor }\end{array}$} & $\begin{array}{l}\text { Believe in consultant with assistant } \\
\text { coaches and subordinates }\end{array}$ & 0.658 & \multirow{10}{*}{0.85} & \multirow{10}{*}{10.65} \\
\hline & Considering medical team emphasize & 0.756 & & \\
\hline & Commitment to team and club goals & 0.766 & & \\
\hline & $\begin{array}{l}\text { Working relationships with other } \\
\text { teams' coaches }\end{array}$ & 0.667 & & \\
\hline & $\begin{array}{l}\text { Good communication with club } \\
\text { managers }\end{array}$ & 0.700 & & \\
\hline & $\begin{array}{lll}\begin{array}{l}\text { Revolutionizing the team } \\
\text { comparison with the past }\end{array} & & \text { in } \\
\end{array}$ & 0.690 & & \\
\hline & Spreading friendship culture in team & 0.641 & & \\
\hline & Developing plans half season & 0.672 & & \\
\hline & The number of victories and defeats & 0.654 & & \\
\hline & $\begin{array}{l}\text { The maintenance and establishment } \\
\text { of effective communication skill with } \\
\text { mass media }\end{array}$ & 0.642 & & \\
\hline \multirow{11}{*}{$\begin{array}{l}\text { Individual- team } \\
\text { management factor }\end{array}$} & $\begin{array}{l}\text { Having plan and program for } \\
\text { employing needed players }\end{array}$ & 0.695 & \multirow{11}{*}{0.79} & \multirow{11}{*}{10.9} \\
\hline & $\begin{array}{l}\text { Correct making decisions in critical } \\
\text { circumstances }\end{array}$ & 0.689 & & \\
\hline & $\begin{array}{l}\text { Improving team or players ability } \\
\text { before the season }\end{array}$ & 0.683 & & \\
\hline & Having the spirit of criticism & 0.671 & & \\
\hline & Having winning spirit & 0.679 & & \\
\hline & $\begin{array}{l}\text { Spreading the spirit of bearing } \\
\text { victories and defeats }\end{array}$ & 0.663 & & \\
\hline & $\begin{array}{l}\text { Planning procurement appointments } \\
\text { and players preparation before the } \\
\text { commence of season }\end{array}$ & 0.668 & & \\
\hline & Solving team conflicts and contrasts & 0.651 & & \\
\hline & $\begin{array}{l}\text { The competency to establish positive } \\
\text { and effective communication with } \\
\text { team players }\end{array}$ & 0.653 & & \\
\hline & $\begin{array}{l}\text { Become familiar with new Goalball } \\
\text { rules and regulations }\end{array}$ & 0.681 & & \\
\hline & $\begin{array}{l}\text { Acquiring knowledge about } \\
\text { specialized sport science (pathology, } \\
\text { physiology of training, nutrition and } \\
\text { psychology) }\end{array}$ & 0.673 & & \\
\hline
\end{tabular}




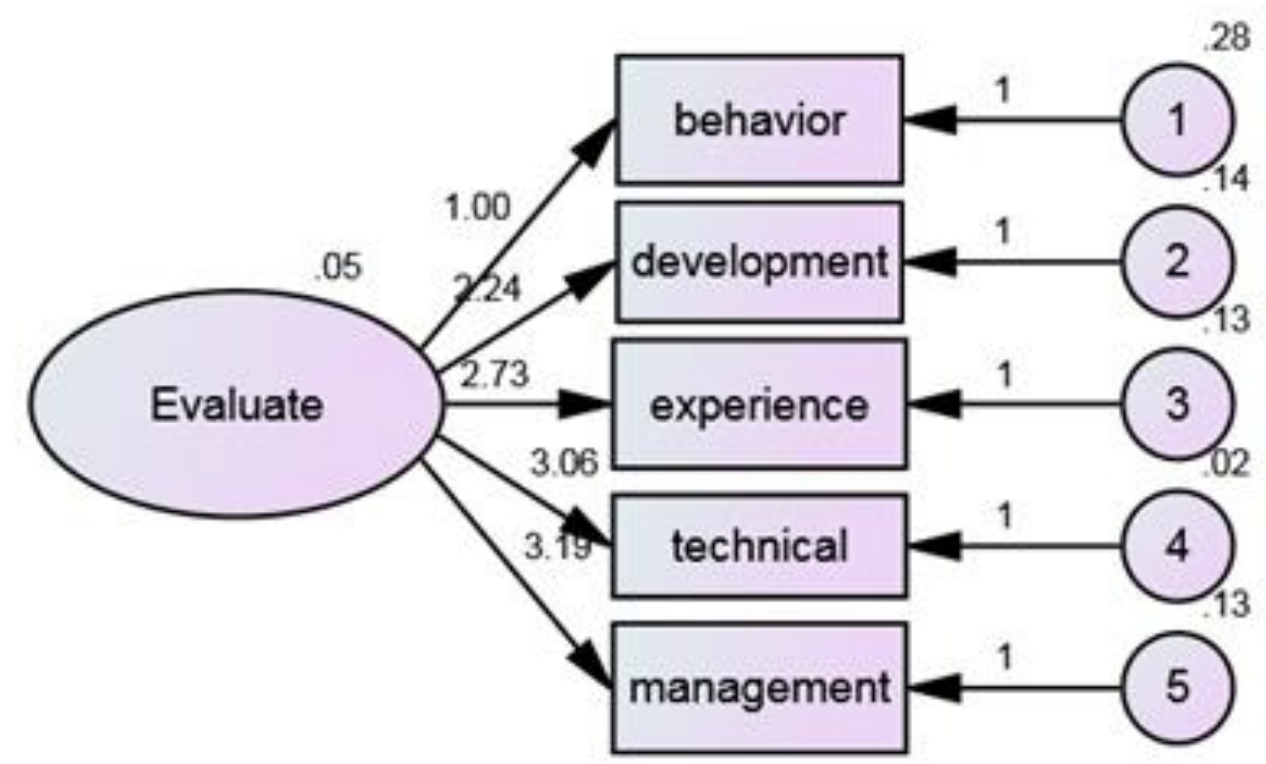

Chi-square $=57.0$ Degrees of freedom Probability level $=.000$

Diagram 1. The results of confirmatory factor analysis. To determine the normality of data distribution Shapiro- wilk test were used, table 3 illustrates the results.

Table 3 . The results of independent t test

\begin{tabular}{cccccc}
\hline factor & category & Mean \pm SD & T & Df & p \\
\hline Technical-educational & $\begin{array}{c}\text { coaches } \\
\text { players }\end{array}$ & $\begin{array}{l}4.46 \pm 0.38 \\
4.35 \pm 0.36\end{array}$ & 2.34 & 145 & 0.018 \\
\hline Behavioral & $\begin{array}{c}\text { coaches } \\
\text { players }\end{array}$ & $\begin{array}{l}4.35 \pm 0.41 \\
4.33 \pm 0.39\end{array}$ & 0.30 & 145 & 0.75 \\
\hline \multirow{2}{*}{ Individual- team management } & $\begin{array}{c}\text { coaches } \\
\text { players }\end{array}$ & $\begin{array}{l}4.33 \pm 0.39 \\
4.18 \pm 0.41\end{array}$ & 2.83 & 145 & 0.013 \\
\hline \multirow{2}{*}{ Coaching experience } & $\begin{array}{c}\text { coaches } \\
\text { players }\end{array}$ & $\begin{array}{l}4.15 \pm 0.46 \\
4.01 \pm 0.47\end{array}$ & 2.47 & 145 & 0.016 \\
\hline \multirow{2}{*}{ Team maintenance and development } & $\begin{array}{c}\text { coaches } \\
\text { players }\end{array}$ & $\begin{array}{l}3.92 \pm 0.48 \\
3.98 \pm 0.45\end{array}$ & 0.73 & 145 & 0.67 \\
\hline
\end{tabular}

$\mathrm{p}<0.05$ is significant

\section{DISCUSSION}

The results of the exploratory factor analysis indicate that Iranian Goalball coaches' performance evaluation factors can be divided into 5 categories. Smaeili and Talebpour (2007) determined 9 factors, Shafiee et al. (2007), Barber and Eckrich (1998) determined 8 factors. MacLean and Chelladurai (1995), MacLean and Zakrajsek (1996), and Hill and Pluschke (2005) determined 6 performance evaluation factors while Nasiri et al. (2009) determined 4 factors. Finally Dehghan et al. (2013) determined 4 factors to measure coaches' performance $(2,3,5,12-16)$.

The analysis of the research findings indicate that factors such as behavioral, technical- educational, experience, maintenance and development and individual-team management are the most important factors for measuring Iranian Goalball coaches' performance. 
In several investigations by MacLean and Chelladurai (1995), MacLean and Zakrajsek (1996), Smaeili and Talebpour (2007) and Dehghan et al. (2013), technical- educational factor, individual- team management factor and experience factor were determined as the main coaches' performance evaluation factors. This corresponds to the current research findings regardless of their ranking and taking into consideration variables which indicate coaches' performance evaluation factors $(3,5,13,15)$.

This indicates that these factors are common and prevalent among the majority of coaches. In the current research, factors such as behavioral factor and maintenance and development factor are determined as Iranian coaches' performance evaluation factors. In fact in other investigations, the two latter factors are named differently with regards to their explanatoryvariables.

It is probable that differences in categorizing factors in various researches are derived from new variables, the number of questions in the questionnaire, the combination of different coaches from various sport fields, the variety of factors or the nature of the sport (the variety in statistical samples and the type of coaches' community such as football, volleyball and etc.).

While in previous researches the numbers of questions in the questionnaire were 40-50 and sometimes 108 questions, the current research had 57 questions in its questionnaire. Moreover, the statistical sample from previous researches covers various sports coaches, while this research covers Goalball coaches only.

In the following, each factor would be investigated separately. Among 5 performance evaluation factors for measuring Iranian coaches' performance, behavioral factor gets the first rank, since all coaches' behavior and conduct affect the players and interactions between coaches and players indicate the coaches' nurturing and role.

It can be considered significant that in addition to technical competencies, coaches should nurture positive behavioral characteristics in themselves. Studies of variables related to behavioral factor in the current research in comparison with previous researches in performance evaluation area indicate taking into consideration variables of this factor and characteristics such as honesty in credits and deeds, provoking motivation in players, dealing with controversial issues around the team and managing it, the ability to increase players tactics, polite and respectful behavior among team players, reconstruction of players' physical and mental power after competitions, relaxation and controlling players stress during competitions, motivation maintenance and valuing player's ability to trust each other, positive thinking spirit and transferring it to players, control and supervision in executing players plans.

Emphasizing and considering players positive characteristics, improving performance and promoting team and players, in fact the ability to communicate with players and considering mental issues have noticeable importance in Iranian Goalball coaches' performance evaluation.

Technical and educational factor is the second influential factor in Iranian Goalball coaches' performance evaluation factor in this research.

This factor reveals that totally from coaches' and players' point of view the following measurements have significant influence on acquiring desirable results and evaluating coaches' performance these measures are elaborated bellow: Analyzing game and competition, High ability to conduct team during competition, Using strategies and techniques proportional to each competition, Ability to train and practice players, Establishing regulations 
and the discipline ofteam, Maintaining team integration, Being decisive in decision making and having static convicts, Planning and appropriate practice execution, Believe in applying knowledge and science in Goalball, Determining the definition of duties for players, Interest in coaching, Controlling the team bench during the competition, Precise scheduling for the execution of team plans, players plans and coaches plans.

This factor reveals that from coaches' and players' points of view, the following measurements have significant influence on achieving desirable results and evaluating coaches' performance. These measures are elaborated bellow: analyzing competition, high ability to conduct team during competition, using strategies and techniques proportional to each competition, ability to train players, establishing regulations and the discipline of the team, maintaining team integration, being decisive in decision making and having static convictions, planning and appropriate practice execution, believe in applying knowledge and science in Goalball, determining the definition of duties for players, interest in coaching, controlling the team's bench during competition, precise scheduling for the execution of team plans, players and coaches plans.

These variables for each factor are determined according to evaluation indexes. Investigated in Shafiee et al. (2007), Barber and Eckrich (1998) and Coaches' Association of British Columbia (2007) researches show, acquiring all skills and the techniques of sport field, selecting various strategies in different games and competitions as well as recognition of different types of game systems is essential to becoming a successful coach. Setting goals, comprehensive practical plans and ability to discover and modify players' technical errors are important technical skills coaches should possess $(2,8,12)$.

A coach's technical characteristics such as awareness of techniques, methods, tactics, rules of related sport fields and analyzing a game and practice, developing strategies, applying feedbacks and coach readiness, applying selfevaluation about practice and competition have significant impact on a coach's location and efficiency. The appropriate combination of motivational strategies, coach's knowledge, ability to conduct, lead and train players, acquiring knowledge about rules, dominance on educational methods result in team achievement and success.

Experience is identified as the third performance evaluation factor for measuring Iranian Goalball coaches' performance. The explanatory variables of this factor reveals that achieving honor as a coach, having first level coaching qualification, passing and developing coach's syllabus, membership in national and international professional associations, coaching experience in national and club levels, the level of a coach's education, coaching in younger age groups or in low level leagues, popularity and fame have high priority in measuring Goalball coaches' performance. The explanatory variables of the experience factor are according to Barber and Eckrich (1998), Shafiee et al. (2007) and Nasiri et al. (2009) $(2,12,16)$. In performance evaluation, experience and coaching records gained through coaching periods affect coaching methods. Moreover, high scientific competency, acquiring essential knowledge in coaching and updating information are influential for coaches' success and evaluation.

Maintenance and development factor is identified as the third performance evaluation factor for measuring Iranian Goalball coaches' performance. The comparison of relevant explanatory variables in current research disclosed that commitment to the goals of team and club, working relationships with other teams' coaches, the number of victories and defeats, spreading friendship culture in team, developing plans for half season, revolutionizing team in comparison with the past, good communication with club managers and heads, believe in consultant with assistant 
coaches and subordinates, considering medical team emphasis and the Maintenance and establishment of effective communication skill with mass media can have influence on performance evaluation. With taking into consideration these results, the coach should have commitment to the goals of club and align his/her behavior in the direction of goals. The coach is expected to communicate appropriately to stakeholders groups, who come into contact with the coach. In addition, having team spirit and the type of coaches behavior with players' traditions and culture affect the coaches' performance. In this research, individual- team management factor has the fifth rank among other factors. In this factor the coach uses his/her abilities to direct the sport plans in order to achieve pre-determined goals. This process refers to planning, organizing, leadership and control. In general, the results of studying and comparing explanatory variables of this factor in current and previous researches indicates that variables such as designing plan and program for employing needed players, correct making decisions when face crisis, improving team or players ability before the season, having the spirit of criticism, having winning spirit, spreading the spirit of bearing victories and defeats, planning procurement appointments and the preparation of players before the commence of season, familiarity with new Goalball rules and regulations, acquiring knowledge about specialized science in realm of sport (pathology, physiology of training, nutrition and psychology) and the competency to establish positive and effective communication with team players have influence on the coach performance evaluation and show the coaches qualifications.

\section{CONCLUSION}

In this study, 5 factors for performance evaluating of professional Goalball coaches were obtained, it is recommended to club managers used their for choose club coaches. As regards in this study, the most important factor in performance evaluating of coaches was technical - education factors, researcher offer to club managers, only by the number of wins and losses of their coaches, not to choose or dismiss their coaches and use from sub-component obtained for choose or dismiss their coaches.

Considering that the viewpoints of the Iranian Goalball players, the most important priority for coaches evaluation was behavioral factor, it's recommended to national blind sports federation during coaching sessions in the context (behavior of coaches) hold briefing classes.

\section{APPLICABLE REMARKS}

- The study was conducted for the first time in the Blind sport Society, before this study, criteria for Goalball national team coaches were not clearly defined, so results of this study can be considered the selection of national team coaches Goalball in Iran.

- Most important criteria for Goalball coaches was behavioraleducational, so this finding suggests that task of blind and visually impaired athletes coaches is very sensitive and before everything a coach needs to be able to find a useful way to interact with your athletes.

- Also, in recent years a lot of attention in the selection of national Goalball coaches is experience, since this factor in prioritizing the investigation was in third place, so Sports Federation practitioners should note that having experience is not a good criterion for choice of coach and before of selection, behavioral and technical factors should be relied. 


\section{ACKNOWLEDGMENTS}

This paper was conducted with material and spiritual support of the Iranian Blind Sports Federation. Researchers need to appreciate efforts of all those who have cooperated in this project Especially $\mathrm{Mr}$. Mohammadreza Mazloumi (president of I.R. Iran blind sports federation).

\section{REFFRENCES}

1. Abdolmaleki H. Goalball training, coaching guide. Iran: Abadi publication; 2015 [Book in Farsi].

2. Shafiee M, Goudarzi M, Hamidi M, YadElahi J, Farsi. Determining And Modeling The National Coaches Selection In Swimming, Diving \& Water Polo In Coaches' Opinion. Harakat. 2007(32):19-36 [Article in Farsi].

3. MacLean JC, Zakrajsek D. Research and Reviews Factors Considered Important for Evaluating Canadian University Athletic Coaches. Journal of Sport Management. 1996;10(4):446-62.

4. Allen J, Shaw S. Women Coaches' Perceptions of Their Sport Organizations' Social Environment: Supporting Coaches' Psychological Needs? The Sport Psychologist. 2009;23(3):346-66.

5. Smaeili M, Talebpour M. Survey, priotrizing and assessment of the coaching dimensions at intercollegiate sport teams. Research on Sport Science. 2007;5(16):92-106 [Article in Farsi].

6. Kavussanu M, Boardley ID, Jutkiewicz N, Vincent S, Ring C. Coaching efficacy and coaching effectiveness: Examining their predictors and comparing coaches' and athletes' reports. The Sport Psychologist. 2008;22(4):383-404.

7. Myers ND, Feltz DL, Maier KS, Wolfe EW, Reckase MD. Athletes' evaluations of their head coach's coaching competency. Research quarterly for exercise and sport. 2006;77(1):111-21.

8. Coaches' Association of British Columbia. 2007 [cited 2015]. Available from: http//www.coachesbc.com.

9. Barron MJ, Powell JW, Ewing ME, Nogle SE, Branta CF. First Aid and Injury Prevention Knowledge of Youth Basketball, Football, and Soccer Coaches. International Journal of Coaching Science. 2009;3(1):55-67.

10. Peng Y, Ming L, editors. Evaluation Index System on Performance Management of Universities High-Level Wushu. 7th International Conference on Innovation \& management; 2011.

11. Myers ND. Coaching Competency and (Exploratory) Structural Equation Modeling: A SubstantiveMethodological Synergy. Psychol Sport Exerc. 2013;14(5):709-18.

12. Barber H, Eckrich J. Methods and Criteria Employed in the Evaluation of Intercollegiate Coaches. Journal of Sport Management. 1998;12(4):301-22.

13. Dehghan A, Ghahfarokhi., Goodarzi M, Jalali M, Farahani., Monazami AH. The Evaluation of the Performance of Iran Volleyball National Team Coaches by 360 Degree Feedback. Sport Physiology \& Sport Management Investigations. 2013;5(2):9-24 [Article in Farsi].

14. Hill GM, Pluschke M. Criteria for Evaluating High School Coaches. IAA. 2005;32(1):14-5.

15. MacLean JC, Chelladurai P. Dimensions of Coaching Performance: Development of a Scale. Journal of Sport Management. 1995;9(2):194-207.

16. Nasiri K, Khabiri M, Sajjadi N, Kazem Nezhad A. The Analysis and Modeling of an Evaluation for Handball National Team Coaches in Iran. Journal of Sport Management. 2009;1(1):119-40 [Article in Farsi]. 
تازههاى علوم كاربردى ورزش

مقاله اصيل

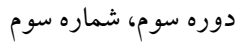

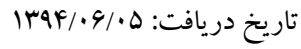

صص و

تاريخ بذيرش:

\section{شناسايى و تحليل شاخصهاى ارزيابى عملكرد مربيان كلبال ايران}

'حسين عبدالملكى، 'زهراسادات ميرزازاده'، 'محبوبه اللهيارى، "محبوبه رمضانى

1. دانشجوى دكترى مديريت ورزشى، دانشكده علوم ورزشى، دانشكاه فردوسى مشهل، مشهلد، ايران.

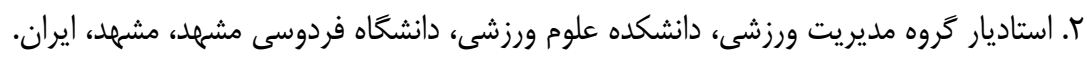

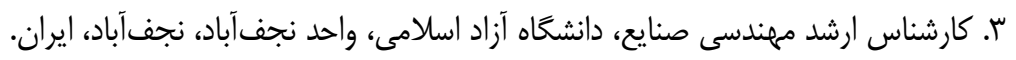

جكيده

ارزيابى و بررسى عملكرد در بخش هاى مختلف ورزش از مسايل مهمى است كه امروزه توجه بسيارى از محققان را به خود جلب كرده است. يكى

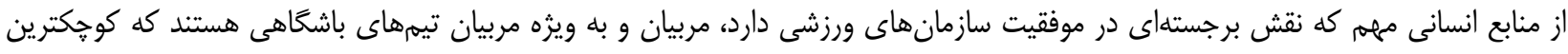

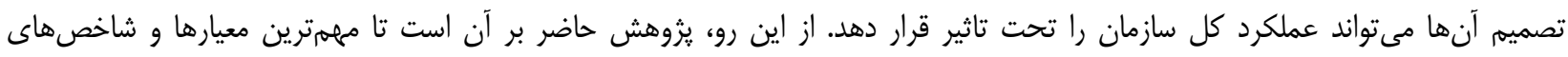

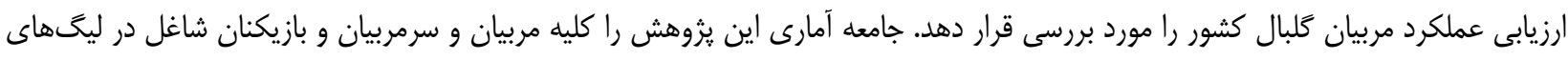

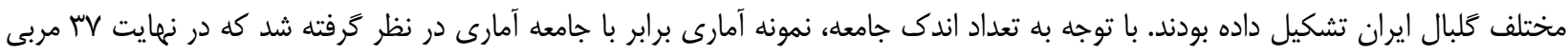

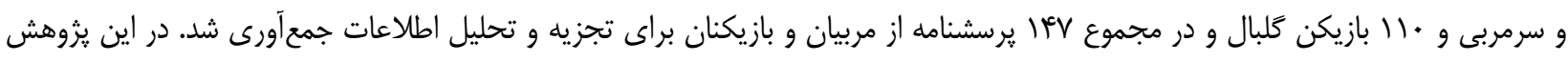

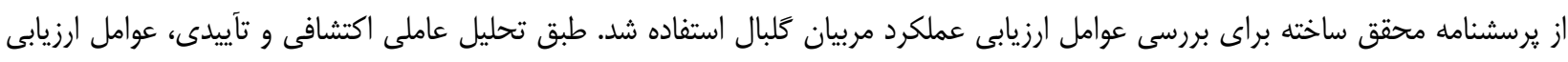

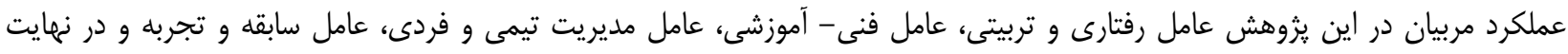

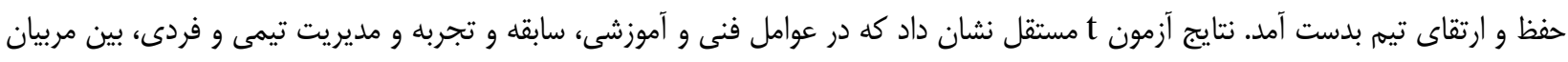

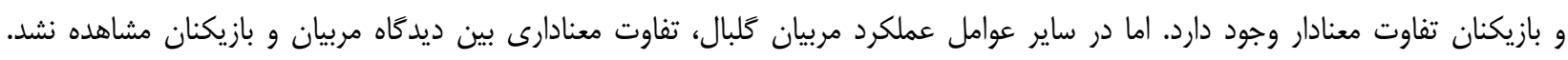

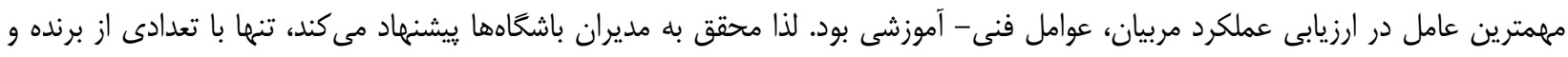

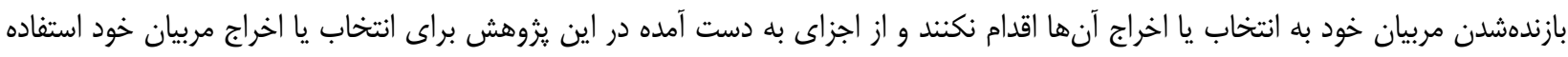
نمايند.

وازكان كليدى: ارزيابى عملكرد، مربى، كلبال، نابينا و كمبينا. 
